International Journal of English Literature and Social Sciences
Vol-6, Issue-4; Jul-Aug, 2021

\title{
O' Lovely Parrot: Vestiges of a Diasporic Jewish Culture
}

\author{
Dr. Shirley Stewart
}

Vice Principal \& Associate Professor, Department of English, Mar Ivanios College, Trivandrum, Kerala, India

Received: 01 Jul 2021; Received in revised form: 20 Jul 2021; Accepted: 30 Jul 2021; Available online: 09 Aug 2021

(C2021 The Author(s). Published by Infogain Publication. This is an open access article under the CC BY license

(https://creativecommons.org/licenses/by/4.0/).

\begin{abstract}
This article tries to look into the concept of Diaspora manifested through the folk songs of the Cochin Jews which celebrates a rich culture and literature. What is known as 'Jewish music' today is thus the result of complex historical processes. But it is to be observed that it is also cornered on the pretext that Cochin Jewish Songs carries certain religious significances only.

The article tries to take a peep into the primary source, "Oh! Lovely Parrot" a compilation of 43 Jewish Malayalam folk songs. The songs in this excellent collection represents a number of little-looked-at corners of Jewish music culture, enacting their diasporic identities through their unique narrative network which include songs, stories and memories.
\end{abstract}

Keywords-Collective Memory, Diaspora, Jewish Songs, Kochi, Piyyutim.

\section{INTRODUCTION}

With the formation of Israel way back in 1948, the migration of the Jewish community who had assimilated themselves into the culture of Kerala started their journey back to their promised land. The history of the Jews, one of the smallest religious groups in India stretches back to two millennia. They trace their ancestry to the days of King Solomon ie even before Jesus Christ. Some historians say they came to Kodungallor and made Mattancherry their space after the Jewish temple was destroyed. Cochin which was their adoptive land still has remnants of this cultural heritage preserved for Historians and travellers as museums especially for those who come searching for their roots. "It is a fact the Jewish diaspora is vanishing from Kerala society. But you cannot ignore our contributions to the State's culture and development. When the Jews arrived here, Kochi was a marshy land and we developed it as a trade Centre. We brought business here. Because of our efforts the city flourished and this fact should be recognised. The Ernakulam Market was under the control of the Jewish community till 1935 and we handed over the rights to the Kochi Municipality in 1935. The government should protect the synagogues as heritage structures. Though the Jewish cemetery near St Teresa's College is a protected monument, it has turned into a dump yard. The cemetery at Mala is being razed and converted into a stadium. We may not live here forever, but these structures are remnants of the past and they should remain," says Elias Josephai, the caretaker of the Kavumbhagam Synagogue.

In Cochin lives a colony of just over a hundred Jews. The diasporic elements of the songs of the Jews of Cochin enthralls and evokes a nostalgic emotion in all listeners . Music is a particularly faithful index of assimilation and so, Jewish religious and folk music have on, the whole reflected with the utmost fidelity, the atmosphere of their Environment. The music of the modern European Jew, the Bogdadian Jew and the Paradesi in Cochin satisfies this great principle in the art of music.

\section{FOLK SONGS OF THE JEWS}

Since the earliest times in history, different cultures throughout the world have usedsongs as a healing force. To understand the significance of Paradesi folk songs in, we need to examine Jewish cultural roots. In the Jewish culture, singing has always been the main means for connecting with the depths of the soul. In modern Hebrew culture, Israelifolk songs play a crucial role in creating a spiritual bond between the people and the country, thus strengthening national as well as self-identity. 
Analysing their songs and its impact on the cultural fabric of Kerala was a journey back to the initial arrival of the Jews in the Indian subcontinent. The Indian Jewish experience was not marked by xenophobia or political oppression but was instead characterised by complex combinations of assimilation, alienation, nostalgia, and patriotism. The origins of the Jewish community in and around Cochin's port city lie in the ancient maritime trading links between the Malabar Coast and West Asia.

Jewish music, in simple words, is the music and melodies of the Jewish people. Here exist both transition of religious music, as sung at the synagogue and domestic prayers and of secular music, such as klezmer. „What is known as 'Jewish music' today is thus the result of complex historical processes. For many centuries, cochin Jewish women have been singing Jewish songs, both in Hebrew and in Malayalamlanguage of Kerala, their homeland on the tropical southwest coast of India. In Kerala, Jewish women sang in Hebrew, together with men, joining in full voice to sing 'piyyutim' in the synagogue, at the Shabbat family table and at community-wide gatherings to celebrate holidays and life cycle events. It is to be noted that, after the expulsion of the Jews from Spain, the Sephardic or Spanish Jews brought along with them the Castilian Dialect and literature which included many folk songs. This explains why, the very large number of melodies- over 500- in use amongst the Paradesi Jews of Cochin and many songs in Hebrew and the Vernacular is unknown to the other Jewish communities of the world.

The remaining of the Cochin Jews thus nurtures their musical heritage through this long and complex historical process. For many centuries, Cochin Jewish women have been singing Jewish songs, both in Hebrew and in Malayalam language of Kerala, their homeland on the tropical southwest coast of India.

The songs they sing or their social or normal lifestyles, truth of their lives is recorded, validated and in no way forgotten. The songs used among the Jews in Cochin can be categorized into the ones written in Hebrew and Malayalam. In addition, the song texts can further be subdivided into many categories according to their ritualistic themes and occasions, namely, Wedding songs, Historical songs , Biblical songs and so on, with the Wedding songs being more prominent and repeatedly sung. The songs are validated or rather formulated on the basis of the various stages during a wedding process be it the making of the ring, the tying of the tali (the traditional Kerala marriage necklace), the bride's emerging from the mikveh, the boiling of raisin wine for the wedding blessings and the procession of the bridegroom to the synagogue. Some feature references to the semi-legendary figure of Joseph Rabban, an ancestral leader of the Kerala Jews. Others contain advice to the bride or the groom-or in a 17 few cases to the parents of a boy at hisbrit mila-about how to lead a good Jewish life. The most commonly sung Jewish weddingsong that describes the beauty of the bride has also been mentioned in this study.

There are biblical and historical songs which are rhythmic manifestations of their vibrant culture. An interesting portion of the analysis was the discovery of song notebooks that included majority of the written texts in terms of verse. These song notebooks, preserved for centuries now can be validated as the most significant and primary document in the study of this music heritage and culture. These songs are collected in notebooks in which the shortest one contains just eight songsand the longest one contains one fifty songs.

\section{DIASPORIC SIGNIFICANCE}

The concept of diaspora in relation to Jewish history was enchanting. Diaspora can be related to alienation, anarchy and epiphany. In this context, the concept of diaspora can be asserted to the forcible scrutinizing of the Jewish people throughout the world. The two main categories of diaspora seen in the Jewish context are capitalised diaspora and noncapitalized diaspora. The diasporic identities of the Jews of Cochin are portrayed through a unique narrative network which includes songs, stories, and memoirs. The diasporic elements have been analysed through the well-known Jewish song collection, 'Oh, Lovely Parrot'. which is in fact a projection of approaches used by the Jews of Kerala to enact their diasporic identities through their unique narrative network including songs, stories and memories providing a valid recognition to the endangered music conveying their traumatic history.

This is because they put their heart and soul to reconstruct a small Israel in Kerala and in addition their unending urge to return to their homeland was very much conveyed through their music tradition.

\section{OH! LOVELY PARROT}

Milk with fruit I shall give - aiyaya

To you, oh my lovely parrot - Aiyaaya

And kovil (guava) fruit I shall pluck for you(Paalum pazhavum tharuven, painkiliye .. parichu tharam njan thathe.

Oh, Lovely Parrot is a compilation of 43 Malayalam folk songs of the Jewish community in Kerala that includes parrot songs, devotional hymns and zionist songs that seek to prepare Jews of Kerala for the migration to Israel. These 
songs are performed in a way which brings together Jewish identities through a collective effort in order to preserve their ethnic memory and social identity. This unique music of Jews held them together even after ' aliyah '( a Hebrew word referring to the migration of Jews to the nation state of Israel post 1948). The songs were passed on to coming generations mostly orally. The preservers and conveyors of this cultural memory were the women. They preserved these songs in small notebooks that were later copied down by others and performed on variousreligious occasions. In the introduction to the book Oh Lovely Parrot, Barbara Johnson states that the "Songs and notebooks travelled from community to community, when brides moved into the homes and congregations of their husbands" (pp. 10). The songs as an affective and memory vehicle brought them together as a community and contained a combination of Jewish and Kerala culture through complex discursive and material markers. In the article "The Parur Songs: Reflections on the Role of Women, " Albrecht Frenz writes about these performances:

When singing the songs, women created an atmosphere of hope. The performanceof the songs constituted a decisive element in the history of the Jewish communityin Kerala. Word, expressions and the way how the songs were performed show that they contain typical Kerala features in terms of landscape, behaviour and the liveliness of performance.

The female voices metonymically and musically transport the past into the present, allowing them to shape uncertain futures with performativity and affective agency. In thisway, the performing women re-created and conveyed meaning and value in the Kerala Jewish cultural fabric through these individual and group activities involving emotional memory and cultural historical materiality. Some of the songs in the collection are named "parrot songs" signifying the three lovely colourful birds as often inscribed in the ketubahor Jewish wedding contract document. Every song is a narrative of embedded experiential memories that the community carried wherever they migrated, containing material as well as messianic markers aimed at creating and consolidating a uniquely aspirational as well as a nostalgically political and religious identity. Through the songs they looked forward as a community to their promised land of Israel, corroborating the complex forward-looking utopian quality of collective memory. Whenever the songs were performed, the remembering subject "actively creates the meaning of the past in the act of remembering" (Smith \& Watson,pp. 16), corroborating how such collective activities in the private as well as public spaces re-present and preserve an economy of cultural memory and identity markers which "offers a productive frame for explaining the social and cultural meaning and value of the act of remembering literature at the individual level"(Skoplijanac,pp.210).

Jewish women along the Malabar Coast filled notebooks with Jewish-themed songs in Malayalam and Hebrew. These notebooks were in the verge of ruins until a series of programs, including scholarly discussions, music and dance and a book exhibition in Washington, DC, attempted to revive that musical heritage.

Inspired by the Washington D.C exhibition, Kerala-born Jew, Galia Hacco, who migratedto Israel as a teenager in the 1950s created a group, the Nirit Singers, which served as a major comeback for the rich Jewish music culture. Hacco, who leads an oral history project in Israel focused on the lives of Cochin women, and Venus Lane, also born in Kerala, were the two members of Nirit Singers who performed at the program, titled 'The Women Who Kept the Songs from India to Israel: The Musical Heritage of Cochin', at the Library of Congress April 7.They also produced the $\mathrm{CD}$ from which songs are borrowed for this article, with lyrics transliterated into Hebrew script by Tzipporah (Venus) Lane for the benefit of younger generations. Their success inspired the efforts of Tova Castiel Aharon, who led a similar Kochini women "e group for several years.

\section{CONCLUSION}

"For every bird there is this last migration" (Hope,A. D., Death of the Bird) the opening lines of A. D. Hope conveys a lot more on how every single Jew dreams of being in Israel and why every music piece hummed their urge to return to their homeland, Israel. While they got implanted to Kerala, it was hard for them at first, to get blended with the culture of Kerala. But the natives of Kerala were always welcoming and warm towards them. The only context in which they left to their homeland was their strong desire to livein Israel, as they believed that it was their promised land. They looked forward to their last migration, their last hope.

\section{REFERENCES}

II Daniel, R. \& Johnson B. C., Ruby of Cochin: An Indian Jewish Women Remembers, Jewish Publication Society, 2002, pp. 174-175.

[2] Frenz, Albrecht, "The Parur Songs; Reflections on the Role of Women, Tapasam: AQuarterly Journal Studies in Malayalam-English, pp.514.

[3] Herman, Simon N., ch. "Criteria for Jewish Identity". Jewish

Identity, SagePublication, Vol. 48, 1977, pp.36.

[4] Hope, A. D., Death of the Bird, Collected Poems 1930-1970, Angus and Robertson, 1972 Jary and Jary, The Collins 
Dictionary of Sociology, Glosgow: Harper Coillins, 1995, pp. 117

[5] Johnson, B. C., "Till the Women Finish Singing: Historical Overview of Cochin Jewish Womenes Malyalam Songs". The Journal of Indo-Judaic Studies, 1st January 2001, pp.83.

[6] Katz, N. Studies of Indian Jewish Identity. Manohar Publications. 2011, pp. 3-4

[7] "Malabari Jews of Kerala: In conversation with Elias Josephai". YouTube, uploaded by Manorama Online, 28th March 2018, youtube.be/ygi6zyrtlmNE

[8] Munshi, Auritra. "Review of Diaspora Theory and Transnationalism by Himadri Lahiri", Spanish Journal of India Studies, Vol. 7, 7th January 2020, pp.93, doi.org/10.5565/rev/insialogs.148, Acessed 11 Feb, 2021

[9] Oh! Lovely Parrot, The Jewish Music Research Center, Spotify,open.spotify.com/track/6WwHE6W7, Accessed 26 Feb 2021

[10] Oommen, G. Z., "Migration and Socio-Cultural Changes Among the Cochin Jews inIsrael". Diaspora Studies, 2008, pp. 29, doi.org/10.2307/26350021

[11] Roony, C, The Encarta Word English Dictionary, Bloomsbury, 1999, pp. 567

[12] Sahoo, Ajaykumar. ch. "Diaspora and Transnational Network: A Conceptual Background”, Transnational Indian Diaspora, Abhijith Publications, 2006, pp.

[13] Simon, A. I. The Songs of the Jews of Cochin and their Historical Significance, Pangal Press, 1947, pp. 5,8

[14] Singh, M. C. Being Indian, Being Israeli: Migration, Ethnicity and the Gender in the Jewish Homeland, Manohar Publications and Distributors, 2014, pp. 30, 69

[15] Skoplijanac, L. "Literature Through Recall: Ways of Connecting Literary Studies and Memory Studies, Interdisciplinary Studies”, 2012, pp. 210

[16] Smith, S. \& Watson J., Reading Autobiography: A Guide for Interpreting Life Narrators,University of Minnesota Press, 2001, pp. 16

[17] Women Who Kept the Songs From India to Israel: The Musical Heritage of www.loc.gov/item/webcast.4825/, Accessed 22 Jan, 2021

[18] Zacharia. S, \& Johnson, B. C(trans), Oh! Lovely Parrot!: Jewish Women"s Songs from Kerala. The Jewish Music Research Center, The Hebrew University of Jerusalerm, 2004, pp. 10,89 